\title{
MODELING THE PROCESS OF FORMATION OF STAGNATION ZONES AT HAZARDOUS PRODUCTION FACILITY WITH APPLICATION OF CFD TECHNOLOGIES
}

Purpose. Early safety assessment of propane-butane storage facilities by modeling the processes of formation of stagnation zones with possible release of gaseous hazardous substances.

Methodology. The presented research uses three-dimensional modeling methods and finite volumes using CFD technologies based on FlowVision software package. It is based on numerical solution of three-dimensional equations of fluid and gas dynamics, including the laws of conservation of mass, momentum (Navier-Stokes equations), and equations of state.

Findings. Using the methods of three-dimensional modeling and finite volumes, stagnation zones in a tank farm were calculated for different wind directions and measurement heights, which made it possible to comprehensively assess the situation at the facility in question and develop measures to improve safety during the operation of the tank farm, as well as recommendations for making changes at the design stage of reservoir parks with propane-butane mixture in order to increase safety of the facility in case of depressurization of equipment.

Originality. It was demonstrated that the buildings located on the territory of the tank farm worsen the movement of air flow, which contributes to formation of stagnation zones of considerable size and, as a result, an increase in potential dispersion time of the probable accidental release of hazardous substances. It has been established that for the object under consideration, the maximum sizes of stagnation zones were observed at the north direction of the wind, and the minimum - at the southeast direction of the wind.

Practical value. Using advanced visualization and data processing tools, we can analyze the calculation results and obtain necessary data relatively quickly and efficiently. The obtained simulation results allow us to do similar studies for objects where an emergency outburst of gaseous substances is possible.

Keywords: stagnation zones, three-dimensional modeling, CFD technology, propane-butane

Introduction. In connection with active growth of industrial production and complexity of technological processes, the issue of ensuring safety of facilities and territories is becoming more and more relevant. At the same time, modern methods and technologies for predicting development of probable accidents make it possible to take into account many parameters, thus increasing reliability of the results of an early forecast. There is a large number of works devoted to application of computational fluid dynamics (CFD) technologies at the stage of safety analysis of objects, but this issue remains relevant until now, because there is no generally accepted methodology for predicting and preventing accidents, as well as rational choice of protective measures.

It is relevant to use these CFD technologies for modeling accidents at facilities where releasing of gaseous hazardous substances is possible. Some of these substances are propane, butane and their mixture, which are of great danger, but at the same time they have become widespread. The impact of aggressive environment, non-compliance with the technological regime of maintenance, untimely scheduled preventive repairs can cause depressurization and destruction of operating equipment. Since propane-butane is heavier than air (specific gravity of propane is 1.57 , that of butane is 2.10 ), it could accumulate in unventilated places, spread over the surface in the direction of air flow over long distances, forming zones of explosive concentrations.

Literature review. There is a significant probability of damage to stations involved in the storage and transportation of propane-butane mixtures (oil refineries and gas refineries, transshipment, port and cluster bases), neighboring facilities and residential settlements. With evaporation of $1 \mathrm{dm}^{3}$ of the liquid phase, about $250 \mathrm{dm}^{3}$ of gaseous phase forms. Therefore, even a small leak of the propane-butane mixture can be

(c) Omelchuk M.V., Korotkova Yu. S., Vorontsova E. A., 2020 dangerous, since the volume of the substance during evaporation can increase by 250 times. In the event of propane-butane ignition, it can be characterized by the rapid development of fire, the explosion of tanks, and the low efficiency of conventional fire extinguishing means.

So, in order to maintain safety, it is necessary to ensure maximum sealing of tanks, communications, pumping units and other equipment, strict adherence to the technological regime of maintenance, and it is recommended that additional systems or techniques be used to predict probable stagnation zones, that is, areas where the wind speed does not exceed $0.5 \mathrm{~m} / \mathrm{s}$.

These scientists have researched such issues as accident modeling: N. N. Krasnogorskaya and V.V.Akhmerov [1], N. N. Belyaev, L. F. Valley, P. S. Kirichenko and V. A. Kozachina [2], Emil Simiu, Donghun Yeo [3], H. Karimaie, B. Nazarian, T.Aurdal, P. H. Nøkleby, O. R. Hansen [4], Robert N. Meroney [5], M. V. Lisanov, S. I. Sumskoy and A. A. Shviryaev [6], V. N. Permyakov, V. G. Parfyonov and M. V. Omelchuk $[7,8]$, and a number of other specialists.

Methods. Recently, CFD technologies were used more often to assess emergency parameters [9]. Now, there are many software systems that implement these technologies [10]. Let us consider the most famous and effective of them, as well as analyze the advantages and disadvantages.

The FLACS software package was developed by Norwegian company GEXCON [11, 12]. The advantages of this software package is an accurate assessment of stagnation zones at a studied object and the zones of propagation of damaging factors, taking into account geometry of the surrounding space, including for explosions in rooms [13]. Nonetheless, the program does not allow one to enter the initial technological data (pressure, temperature, defective hole size) for the required equipment. It is also important to mention that the disadvantage is the complexity of preparing the source data of geometry 
of the surrounding space (parameters of room, building, structures, terrain), and to operate the program requires a high level of user skill.

The software package ABAQUS has been created by American company Abaqus Inc. Advantages are the possibility of analyzing effects of air blast waves, calculating linear structures taking into account climatic conditions, modeling air flows taking into account complex geometry, allowing calculating probable stagnation zones [14]. We should mention the reliability of the software package, strict control over the convergence of the solutions of the studied processes, ability to automatically select the integration step and monitor tasks at all stages of calculation. A significant drawback is high cost and inability to calculate parameters of ventilation and air conditioning, as well as predicting the spread of fires and smoke.

The ANSYS program was developed by American company Ansys Inc. The advantage is ability to build a 3D model in the program itself without the use of additional computer aided design (CAD) systems. This program allows one to solve many complex problems, including distribution of gas emissions in the atmosphere, assessment of wind comfort factors in construction conditions and the calculation of stagnation zones, modeling the processes of development of fires and firefighting. It is possible to obtain calculation results in form of video files with simulation dynamics. The disadvantages are high cost and complexity of learning to operate.

The FlowVision software package was created by the development team of TESIS LLC (Russia). The main advantages are the ability to simulate the distribution of the gas cloud, calculate the wind load, the external flow around structures and probable stagnation zones, predict the spread of pollutants in water bodies, calculate ventilation and air conditioning parameters, and predict the spread of fires and smoke $[15,16]$.

Each of the abovementioned software systems and methods has its advantages and disadvantages, but after analyzing the functionality, FlowVision can be distinguished due to its relative ease of use, comprehensive and understandable documentation, reliability of results, good user support, high quality and the ability to solve complex safety problems and environmental protection in enterprises. It is also important to mention that this software package has a relatively low cost and is available for calculations in educational institutions.

The presented study uses methods of three-dimensional modeling and finite volumes using CFD technologies based on FlowVision software package. It is based on numerical solution of three-dimensional equations of fluid and gas dynamics, including the laws of conservation of mass, momentum (Navier-Stokes equations), and equations of state. It is important to note that the capabilities of this complex allow us to create effective systems for predicting and preventing accidents, as well as make a rational choice of protective measures using advanced means of visualization and data processing. It is also possible to select necessary physical and chemical parameters of the environment (temperature, pressure, wind speed and direction) for the simulated object and propanebutane mixture (pressure, mass fraction, viscosity, thermal conductivity, specific heat, and others), as well as the necessary dynamics characterizing the flow, mass transfer and interaction of the mixture.

Results. In the presented research, a propane-butane tank farm with an area of 30 thousand $\mathrm{m}^{2}$ was selected as a modeling object (Fig. 1). When creating the three-dimensional model, CAD SolidWorks was used.

It should be noted that SolidWorks applies 3D modeling method using the construction tree, according to which the model is divided into structural elements controlled by dimensions during its construction and editing. Thus, changes in geometry, carried out automatically, are reliable and predictable. One of the features of SolidWorks CAD is $100 \%$ compliance with the requirements of the unified system of design documentation when making drawings, the presence of international standards; it uses the simplest geometric shapes and is interconnected by indicating dimensions and relationships. In order to make further research, it is possible to choose the binding of objects. Therefore, you can move objects in the direction of the $X, Y$, and $Z$ axes (axonometric).

In area of the object under consideration, there are no sources of water intake, artificial reservoirs, ditches and ravines. With the use of railway tanks, propane-butane is transported, received and pumped into tanks. The propane-butane is drained from the railway tanks into the tank farm capacities through gas pipelines located above the earth's surface, through drain posts under gas pressure. Liquefied propane-butane mixture is stored in each tank. Compressor equipment is located in a structure under canopy. The pump at the PCC takes the liquid phase, and with the compressor, the vapor is taken into the tank capacity. The probable areas of depressurization of equipment on and the territory being investigated are:

- reservoir park;

- drain and bulk railway overpass;

- cylinder filling shop;

- equipment located in an PCC;

- pipelines.

The cause of the occurrence and development of accidents on the components of the studied object may be the following technical problems:

- ruptures of pipelines, flexible hoses (sleeves) due to corrosion, mechanical damage, pressure increase beyond design, and wear;

- depressurization of stuffing box and mechanical seals of pumps, compressors, gate shutters, valves;

- destruction of containers because of mechanical damage, corrosion, thermal effects;
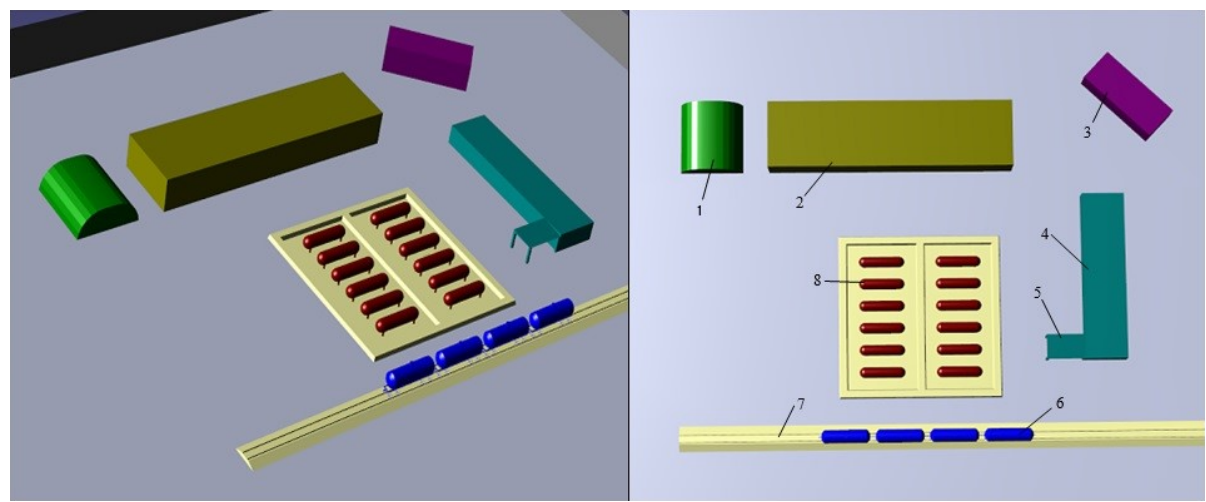

Fig. 1. Appearance of the studied propane-butane storage tank farm (side and top view):

1 - arched hangar; 2 - machine shop; 3 - administrative-household complex (AHC); 4 - cylinder filling shop; 5 - pump and compressor compartment (PCC); 6 - railway tanks with a volume of $54 \mathrm{~m}^{3}$ each; 7 - railway embankment; 8 - tanks with a volume of $50 \mathrm{~m}^{3}$ each 
- destruction of tanks because of their overflow and thermal deformation during expansion of liquefied gas;

- loose valves, gate valves, and taps;

- various breakdowns on tanks (drainage valves, level gauges, safety shutoff valves);

- breakdowns of flange joints of pump, compressor, evaporator pipings: breakdowns of the stuffing box packing of pumps or compressors [1].

An important part in modeling the process of formation of stagnation zones is the computational grid. In these calculations, a grid with a total number of cells of 1.6 million was used. Modeling of computational domain was carried out using an adaptive grid with local refinement in areas of complex geometric shape. This approach provides, on the one hand, the use of a simple uniform non-adaptive grid when solving problems with relatively simple geometry. On the other hand, it becomes possible to solve forecasting problems with complex geometry of an industrial object by adapting the grid to the geometry of industrial objects. The local grinding procedure in field of adaptation provides for the possibility of sequential division, starting from the initial, of each previous cell, into smaller cells until the adaptation condition is satisfied. The integration step in modeling the movement of wind flows is set in seconds and is equal to $0.1 \mathrm{~s}$. At the same time, the selected step allows obtaining the necessary results faster, and also such a scheme is highly stable for problems with turbulent gas flow.

When modeling, the development of the object of study, wind speed $(2 \mathrm{~m} / \mathrm{s})$, wind direction, air temperature $(293 \mathrm{~K})$ are taken into account. It is also important to consider the change in pressure over the height, since gas density is different with height. The work implements a barometric pressure distribution formula for isothermal atmosphere, specified in the program using formula

$$
P=P_{0} \cdot e^{\left(-\frac{M \cdot g \cdot h}{R \cdot T}\right)},
$$

where $P_{0}$ is the pressure at the surface of the earth, $\mathrm{Pa}\left(P_{0}=\right.$ $=101000 \mathrm{~Pa}) ; M$ is the molar mass of air, $\mathrm{kg} / \mathrm{mol}(M=$ $=0.028964 \mathrm{~kg} / \mathrm{mol}) ; g$ is the acceleration of gravity, $\mathrm{N} / \mathrm{kg}(g=$ $=9.8 \mathrm{~N} / \mathrm{kg}) ; h$ is the height specified in the program using the $Y$ coordinate, $\mathrm{m} ; R$ is the universal gas constant, $(R=$ $=8.31441 \mathrm{~J} /(\mathrm{mol} \cdot \mathrm{K})) ; T$ is the temperature $(T=293 \mathrm{~K})$.
After exporting the model from SolidWorks CAD to FlowVision software package and loading the environmental parameters and setting boundary conditions, the model looks as follows (Fig. 1).

Through the use of the FlowVision software package, probable stagnation zones were determined for different wind directions for speed of $2 \mathrm{~m} / \mathrm{s}$ at altitudes of $0.2 ; 0.5 ; 1.0 ; 1.5$; 2.0; 2.5; and $3.0 \mathrm{~m}$; some of them are presented in Figs. 2, 3 . The stagnation zones in the figures are presented by shades of blue. The wind rose for the city Tyumen (Russia) was also taken into account.

As can be seen from Figs. 2, 3, the presence of buildings in territory of the model significantly worsens the air flow, which results in presence of large areas of stagnation zones. For clarity of the results obtained, Figs. 4-7 present the calculated areas occupied by structures, stagnation zones and zones where the wind speed is more than $0.5 \mathrm{~m} / \mathrm{s}$ at general wind speed of $2 \mathrm{~m} / \mathrm{s}$.

Therefore, it was found that the maximum area of stagnation zones is observed with the north direction of the wind at altitudes of $0.2 ; 0.5 ; 1.0 ; 1.5 ; 2.0 ; 2.5$; and $3.0 \mathrm{~m}$ above the ground $\left(2044 ; 1758 ; 2467 ; 2539 ; 2950 ; 3279 ; 3538 \mathrm{~m}^{2}\right.$, respectively), and the minimum - with the southeast direction of the wind $\left(380 ; 384 ; 270 ; 147 ; 122 ; 106 ; 105 \mathrm{~m}^{2}\right.$, respectively).

Discussion. In the area of emergency modeling, there are studies aimed both at predicting the formation of a gas cloud and at modeling the behavior of gaseous media in other situations. Unfortunately, the authors of such scientific papers give little attention to stagnation zones or do not pay attention at all. The works of the following authors should be noted.

Emil Simiu and Donghun Yeo examined the issues of atmospheric thermo- and hydrodynamics, wind climatology and its impact on design and calculation of engineering structures, demonstrated the dependence of the wind load and its distribution on buildings and structures on the wind speed and concluded that model tests for wind exposure are necessary for calculation and design of structures [3].

Robert N. Meroney conducted a laboratory research to model emissions into the boundary layer of the earth necessary to describe the movements of potentially hazardous chemicals, including propane, butane, liquefied natural gas, freon, identified modeling criteria and the results of behavior of a dense plume in a wind tunnel, which can be used to em-
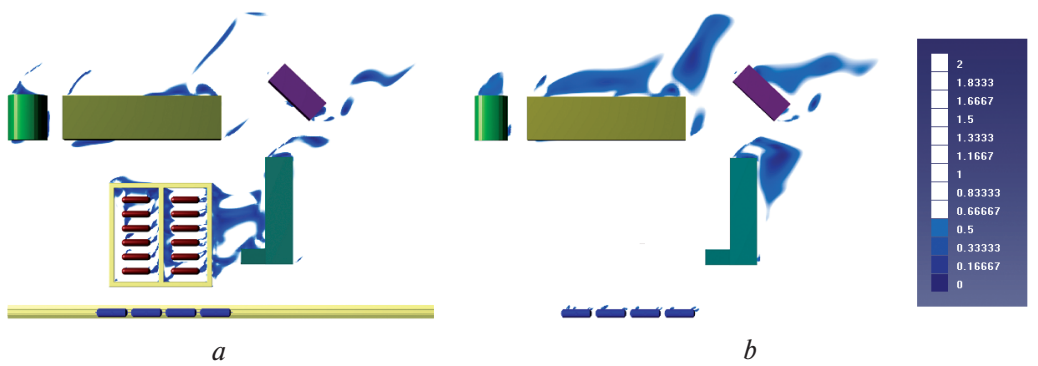

Fig. 2. An example of stagnation zones in the south-west direction of wind (speed $2 \mathrm{~m} / \mathrm{s}$, top view):

$a$ - at a height of $0.2 \mathrm{~m} ; \mathrm{b}-$ at a height of $3.0 \mathrm{~m}$
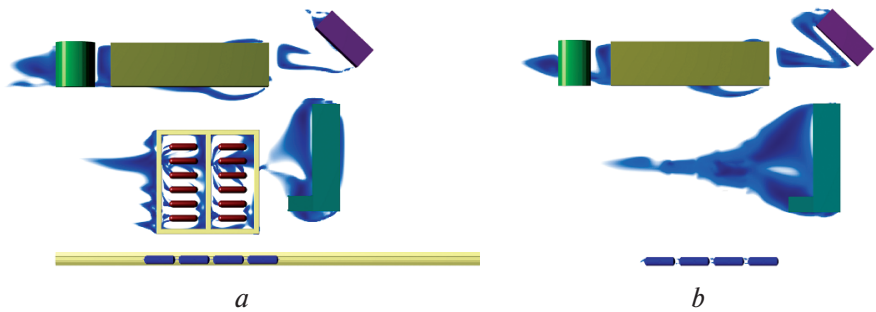

Fig. 3. An example of stagnation zones in the eastern direction of the wind (speed $2 \mathrm{~m} / \mathrm{s}$, top view):

$a$ - at height of $0.2 \mathrm{~m} ; b-$ at height of $3.0 \mathrm{~m}$ 


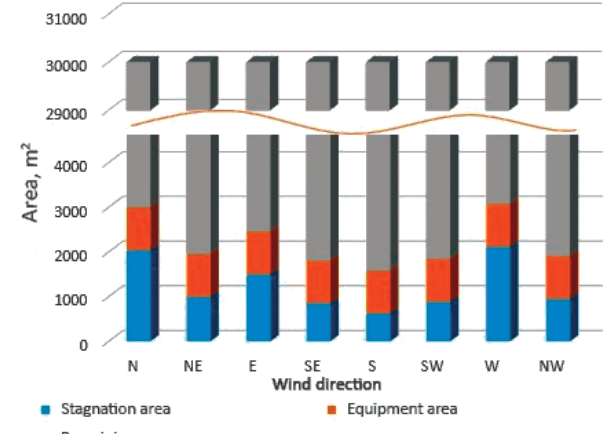

$a$

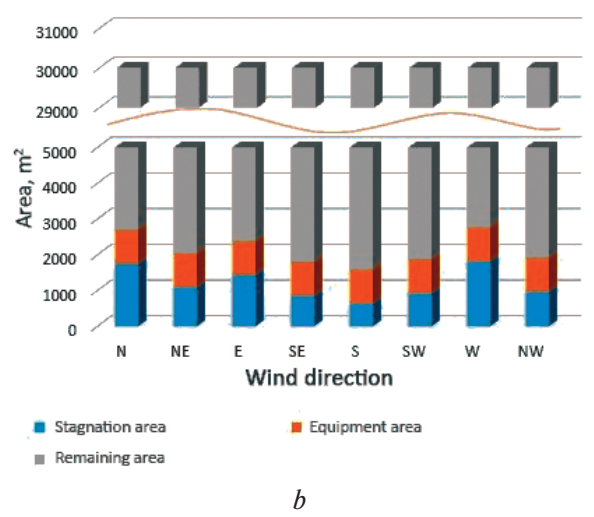

$b$

Fig. 4. The dependence of sizes of probable stagnation zones, equipment area and remaining territory on the wind direction: $a$ - at height of $0.2 \mathrm{~m} ; \mathrm{b}$ - at height of $0.5 \mathrm{~m}$

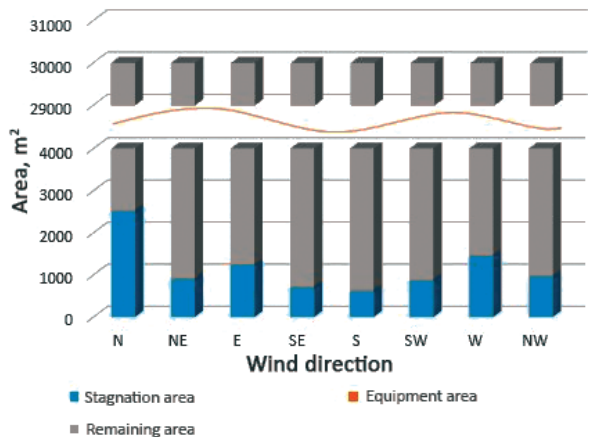

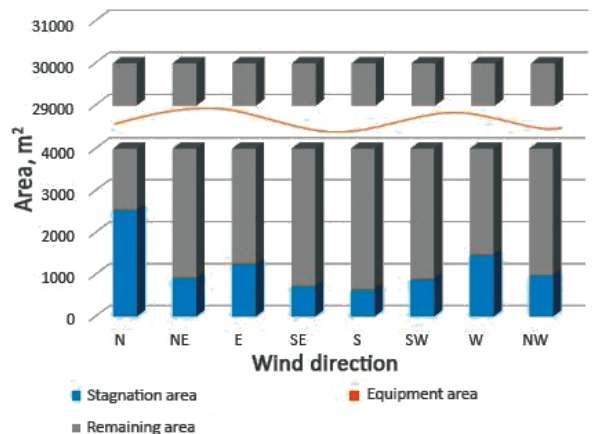

$b$

Fig. 5. Dependence of sizes of probable stagnation zones, equipment area and remaining territory on the wind direction: $a$-at height of $1.0 \mathrm{~m} ; \mathrm{b}-$ at height of $1.5 \mathrm{~m}$

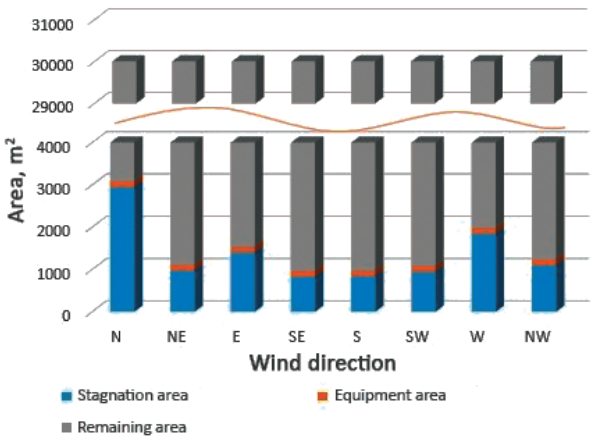

$a$

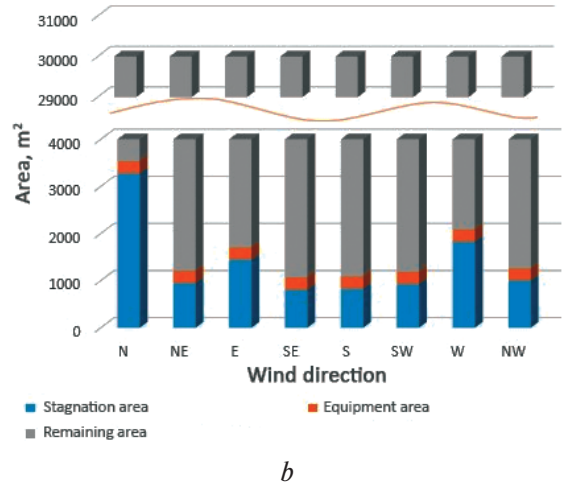

$b$

Fig. 6. Dependence of sizes of probable stagnation zones, equipment area and remaining territory on the wind direction: $a-$ at height of $2.0 \mathrm{~m} ; \mathrm{b}-$ at height of $2.5 \mathrm{~m}$

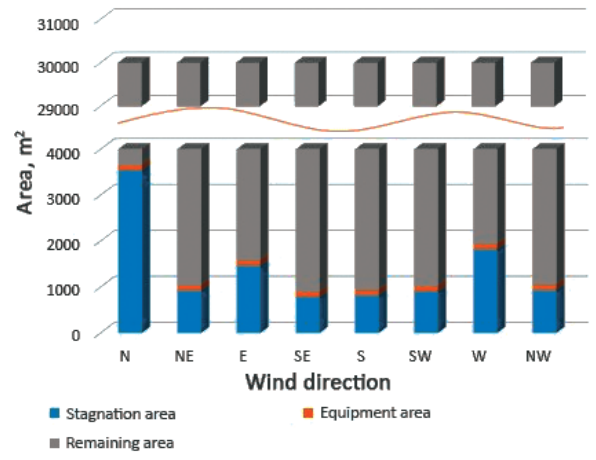

Fig. 7. Dependence of sizes of probable stagnation zones, equipment area and the remaining territory on the wind direction at height of $3.0 \mathrm{~m}$ above the ground pirically predict the dispersion of steam from full-scale emissions [5].

Lisanov M. V., Sumskoy S. I., Shiryaev A. A. in their work examined a number of issues related to modeling dispersion in the atmosphere and assessing the effects of toxic and fire and explosion hazardous emissions using the TOXI-3 methodology. This technique was developed by the Federal State Unitary Enterprise STC "Industrial Safety" and allows calculating the characteristics of a dangerous cloud moving in the atmosphere within the framework of the "heavy gas" dispersion model, which is based on the integral conservation laws. The calculation of various options for dispersion of ejection was made: short and long, in the presence of obstacles and without them. Then, it was concluded that standard techniques based on the Gaussian model are not suitable to predict the scattering of "heavy gas" with a sufficient degree of accuracy, both 
from short and long-acting source. The magnitude of error was 400-500\%. The TOXI-3 technique has demonstrated good ability to predict concentration fields and cloud sizes for emissions from long-term sources. Calculations using this technique are in good agreement with experimental data [6].

The relevance of finding the size of stagnation zones for objects with a probable propane-butane yield was considered in the studies of such scientists as R. R. Tlyasheva, A. V. Solodovnikov, V. N. Permyakov, M. V. Omelchuk, N. N. Krasnogorskaya and V. V. Akhmerov. As in the study presented in the article, these authors directly linked the size of stagnation zones with safety of the facility and when modeling took into account the real development of the production facility and the terrain $[1,7]$.

Krasnogorskaya N.N. and Akhmerov V.V. noted that studies provided by R. R. Tlyasheva and A. V. Solodovnikov are of a deep nature and are aimed at improving the safety of typical outdoor area of an absorption-gas fractionating unit [1]. As in the research results presented in the article, R. R. Tlyasheva and A. V. Solodovnikov talk about need to take into account the size of stagnation zones at the stage of designing an object, but at the same time, in their recommendations for spaceplanning decisions, considerable emphasis is placed on turning the object around its axis in order to minimize the likelihood of stagnation zones of significant dimensions. It should be mentioned that these authors proposed an interesting algorithm for the optimal placement of gas analyzers on the territory of production facility. Compared to the works by A. V. Solodovnikov and R. R. Tlyasheva, the research presented in the article analyzes stagnation zones at a liquefied petroleum gas storage facility.

The joint research by V.N. Permyakov and M.V. Omelchuk presents an assessment of stagnation zones for a typical gas filling station, which made it possible to find the optimal location of structures on the tank farm site. Also, for the first time, a methodology for assessing safety of light hydrocarbon storage facilities in emergency situations was developed, scientifically substantiated and confirmed by laboratory studies, which allows a comprehensive assessment of stagnation zones using three-dimensional modeling systems and finding the most effective solution for ensuring safety at all stages of the object's life cycle [7]. Compared with the studies by V. N. Permyakov and M. V. Omelchuk, in the presented study, stagnation zones are assessed at a greater number of heights, the storage facility is somewhat simplified, the most common components are left, but at the same time tanks on the railway overpass are added.

Krasnogorskaya N. N. and Akhmerov V. V. chose a gas station (multi- fuel station) with multi-product dispensers as the object of research. The authors solved the problems of finding stagnation zones and formation of cloud of fuel liquefied hydrocarbon gases on the territory of this facility. The research proposed an algorithm for selecting measures to improve operational safety of integrated gas station and recommendations aimed at reducing the likelihood of the formation of LPG fuel assemblies in technological process of gas stations, to improve the dispersion of explosive fuel vapors at the site of multiproduct fuel dispensers, and to increase the efficiency of accident elimination process [1]. Compared with the scientific research by N. N. Krasnogorskaya and V.V.Akhmerov, in the presented study, an object for storing a propane-butane mixture was simulated, in which the probable volume of cloud of fuel-air mixture was ten times larger.

Unlike all the above mentioned studies of scientists, in the presented work, the calculation of probable stagnation zones was carried out with the wind speed typical for Tyumen (Russia), at the same time taking into account the wind rose characteristic of this territory. For this calculation, the new generation FlowVision software package was used.

Conclusions. With the help of methods of three-dimensional modeling for finite volumes, stagnation zones in the tank farm were calculated for different wind directions and measuring heights, which made it possible to comprehensively assess the situation at the facility in question and to develop a number of measures to improve safety:

1. Changing the height of tanks.

2. Safety provisions at the design and construction stage, including rational location of tank farm facilities depending on distance between the facilities and the wind rose.

3 . The choice of rational arrangement of gas analysis sensors.

4. Analysis of possibility of implementing technical measures aimed at improving the safety of the facility.

The importance of modern safety tasks requires intensive development of applications, without which it is almost impossible to create effective systems for predicting and preventing accidents. Therefore, it makes the task of developing new approaches based on using three-dimensional modeling and CFD technologies relevant. Using advanced visualization and data processing tools, we can analyze the calculation results and obtain necessary data relatively quickly and efficiently.

\section{References.}

1. Krasnogorskaya, N. N., \& Akhmerov, V. V. (2015). Development of an Event Selection Algorithm to Enhance the Security of an Integrated Gas Station. In the world of scientific discoveries, 6(1), 476-487.

2. Biliaiev, M., Dolina, L., Kirichenko, P., \& Kozachyna, V. (2018). Air Pollution near Piles Having Comprehensive Form. Proceedings of the National Mining University, 53, 237-243.

3. Simiu, E., \& Yeo, D. (2015). Advances in the Design of High-Rise Structures by the Wind Tunnel Procedure: Conceptual Framework. Wind and Structures, an International Journal, 21(5), 489-503. https://doi.org/10.12989/ was.2015.21.5.489.

4. Karimaie, H., Nazarian, B., Aurdal, T., Nøkleby, P.H., \& Hansen, O. (2017). Simulation Study of $\mathrm{CO}_{2}$ EOR and Storage Potential in a North Sea Reservoir. Energy Procedia, 114, 7018-7032. https://doi.org/10.1016/j.egypro.2017.03.1843.

5. Meroney, R. N. (2017). Prospecting for Wind Energy. International Telemetering Conference (Proceedings), 2(2), 736-740. 6. Lisanov, M. V., Sumskoy, S. I., \& Shvyryayev, A.A. (2018). Uncertainties of Quantitative Risk Assessment of Accidents at Oil and Gas Facilities. News of Gas Science, 2(34), 125-134.

7. Permyakov, V.N., Parfenov, V.G., \& Omelchuk, M.V. (2015). Methods for Assessing the Sustainability of Storage Facilities for Liquefied Hydrocarbon Gases. Security and Emergency Issues, 6, 73-79.

8. Permyakov, V. N., \& Omelchuk, M. V. (2015). Field Verification of the Adequacy of Computational Results. Natural and Technical Sciences, 9(87), 151-153.

9. Agranat, V., Malin, M., Abdullah, R., \& Pioro, I. (2015). CFD Analysis of turbulent Mixed Convection Upward Flow of Supercritical Water in a Vertical Tube. International Topical Meeting on Nuclear Reactor Thermal Hydraulics, 10, 84268439.

10. Wen, T., Luo, Y., He, W., Gang, W., \& Sheng, L. (2019). Development of a Novel Quasi-3D Model to Investigate the Performance of a Falling Film Dehumidifier with CFD Technology. International Journal of Heat and Mass Transfer, 132, 431-442. https://doi.org/10.1016/j.ijheatmasstransfer.2018.12.027.

11. Tao, W., Yimo, L., \& Lin, L. (2019). A Novel 3D Simulation Model for Investigating Liquid Desiccant Dehumidification Performance Based on CFD Technology. Applied Energy, 240, 486-498. https://doi.org/10.1016/j.apenergy.2019.02.068. 12. Bentaib, A., Meynet, N., \& Bleyer, A. (2015). Overview on Hydrogen Risk Research and Development Activities: Methodology and Open Issues. Nuclear Engineering and Technology, 47(1), 26-32. https://doi.org/10.1016/j.net.2014.12.001.

13. Agapova, E. A., Degtyarev, D. V., Lisanov, M. V., \& Kryukov, A.S. (2015). Comparative Analysis of Russian and Foreign Methods and Computer Programs for Modeling Acci- 
dental Emissions and Risk Assessment. Labor Safety in Industry, 9, 71-78.

14. Evseev, D. P. (2017). Use of the Abaqus Software Package for the Calculation of Building Structures. Trends in the Development of Science and Education, 23(3), 26-28.

15. Aksenov, A.A., Zhluktov, S. V., Savitskiy, D. V., Bartenev, G. Y., \& Pokhilko, V. I. (2015). Simulation of 3D Flows Past Hypersonic Vehicles in Flowvision Software. Journal of Physics: Conference Series, 653(1), 012072. https://doi. org/10.1088/1742-6596/653/1/01207.

16. Omelchuk, M.V., Korotkova, Y.S., \& Vorontsova, E.A. (2019). Estimation of the Size of Stagnation Zones on the Territory of the Propane-Butane Tank Farm Aimed at Increasing the Safety of the Facility. Periodico Tche Quimica, 16(32), 656-667.

\section{Моделювання процесу формування зон застою на небезпечному виробничому об'єкті із застосуванням CFD-технологій}

\section{М. В. Омельчук ${ }^{1}$ Ю. С. Короткова ${ }^{2}$, Е.А. Воронцова ${ }^{3}$}

1 - Тюменський індустріальний університет, м. Тюмень, Російська Федерація, e-mail: omelchuk.mv@mail.ru 2 - ТОВ «ІПІГАЗ», м. Тюмень, Російська Федерація 3 - АТ «НІПІГАЗ», м. Тюмень, Російська Федерація

Мета. Завчасна оцінка безпеки об'єктів зберігання пропан-бутану шляхом моделювання процесів формування зон застою при можливому викиді газоподібних небезпечних речовин.

Методика. У представленому дослідженні використовуються методи тривимірного моделювання й кінцевих обсягів з використанням CFD-технологій на базі програмного комплексу FlowVision. Він базується на чисельному рішенні тривимірних рівнянь динаміки рідини й газу, що включають у себе закони збереження маси, імпульсу (рівняння Нав'є-Стокса), рівняння стану.

Результати. За допомогою методів тривимірного моделювання й кінцевих обсягів були розраховані зони застою в резервуарному парку за різних напрямків вітру й висоті вимірів, що дозволило комплексно оцінити ситуацію на даному об'єкті й розробити заходи щодо підвищення безпеки при експлуатації резервуарного парку, а також рекомендації щодо внесення змін на стадії проектування резервуарних парків із пропан-бутановою сумішшю з метою підвищення безпеки об'єкта в разі розгерметизації обладнання.

Наукова новизна. Показано, що споруди, розміщені на території резервуарного парку, погіршують рух повітряного потоку, що сприяє утворенню зон застою значних розмірів i, як наслідок, збільшення потенційного часу розсіювання ймовірного аварійного викиду небезпечних речовин. Встановлено, що для даного об'єкту максимальні розміри зон застою спостерігаються при північному напрямку вітру, а мінімальні - при південносхідному напрямку вітру.

Практична значимість. За допомогою передових засобів візуалізації та обробки даних можна відносно швидко та ефективно проаналізувати результати розрахунків i отримати необхідні дані. Отримані результати моделювання дозволяють проводити аналогічні дослідження для об’єктів, де можливий аварійний вихід газоподібних речовин.

Ключові слова: зони застою, тривимірне моделювання, CFD-технології, пропан-бутан

\section{Моделирование процесса формирования зон застоя на опасном производственном объекте с применением CFD-технологий}

\author{
М. В. Омельчук ${ }^{1}$ Ю. С. Короткова ${ }^{2}$, Е.А. Воронцова
}

1 - Тюменский индустриальный университет, г. Тюмень, Российская Федерация, e-mail: omelchuk.mv@mail.ru 2 - ООО «ИПИГАЗ», г. Тюмень, Российская Федерация 3 - АО «НИПИГАЗ», г. Тюмень, Российская Федерация

Цель. Заблаговременная оценка безопасности объектов хранения пропан-бутана путем моделирования процессов формирования зон застоя при возможном выбросе газообразных опасных веществ.

Методика. В представленном исследовании используются методы трехмерного моделирования и конечных объемов с использованием CFD-технологий на базе программного комплекса FlowVision. Он базируется на численном решении трехмерных уравнений динамики жидкости и газа, включающие в себя законы сохранения массы, импульса (уравнения Навье-Стокса), уравнения состояния.

Результаты. С помощью методов трехмерного моделирования и конечных объемов были рассчитаны зоны застоя в резервуарном парке при разных направлениях ветра и высоте замеров, что позволило комплексно оценить ситуацию на рассматриваемом объекте и разработать мероприятия по повышению безопасности при эксплуатации резервуарного парка, а также рекомендации по внесению изменений на стадии проектирования резервуарных парков с пропан-бутановой смесью с целью повышения безопасности объекта в случае разгерметизации оборудования.

Научная новизна. Показано, что постройки, размещенные на территории резервуарного парка, ухудшают движение воздушного потока, что способствует образованию зон застоя значительных размеров и, как следствие, увеличению потенциального времени рассеивания вероятного аварийного выброса опасных веществ. Установлено, что для рассматриваемого объекта максимальные размеры зон застоя наблюдаются при северном направлении ветра, а минимальные - при юго-восточном направлении ветра.

Практическая значимость. С помощью передовых средств визуализации и обработки данных можно относительно быстро и эффективно проанализировать результаты расчетов и получить необходимые данные. Полученные результаты моделирования позволяют проводить аналогичные исследования для объектов, где возможен аварийный выход газообразных веществ.

Ключевые слова: зоны застоя, трехмерное моделирование, CFD-технологии, пропан-бутан

Recommended for publication by O.M. Anashenkov, Doctor of Technical Sciences. The manuscript was submitted 08.05.19. 